\title{
Atributos da encontrabilidade da informação e a desmobilização da postura ativa do usuário da Web
}

\author{
Sergio Mari Junior \\ Doutorando; Universidade Estadual de Londrina, Londrina, PR, Brasil; \\ sergio@cedilha.com.br \\ Miguel Luiz Contani \\ Doutor; Universidade Estadual de Londrina, Londrina, PR, Brasil; \\ mcontani@gmail.com
}

\begin{abstract}
Resumo: A World Wide Web revolucionou o modo como consumimos informação, demandando dos usuários postura ativa na busca pelos conteúdos. Mais recentemente, as redes sociais na Internet ofereceram ainda mais liberdades e possibilidades de ação, porém também foram responsáveis por popularizar os ambientes informacionais conhecidos como timelines. Nesses ambientes, os conteúdos apresentados são selecionados automaticamente, por meio de algoritmos. $\mathrm{O}$ estudo deste artigo tem o objetivo de evidenciar de que forma a dinâmica e a arquitetura da informação utilizadas nas timelines contribuem para o retorno a uma postura passiva por parte do usuário. Emprega a análise dos atributos da Encontrabilidade da Informação como metodologia, verificando o modo como são aplicados nas timelines. A análise indicou evidências de que tais ambientes atendem a poucos atributos da Encontrabilidade da Informação, permitindo concluir que foram projetadas para um usuário indiferente, que não procura adotar postura ativa na busca pela informação.
\end{abstract}

Palavras-chave: Encontrabilidade da informação. Redes sociais na Internet. Web Social. Timelines.

\section{Introdução}

O computador (surgido por volta dos anos 1940 e 1950), a Internet (surgida na década de 1960) e a World Wide Web (ou simplesmente Web, surgida na década de 1990) se combinaram para criar uma nova categoria de meio de comunicação: as mídias digitais. Depois das mídias impressas (inauguradas pela prensa de tipos móveis de Gutemberg e pelo jornal no século XV) e das mídias eletrônicas (baseadas na transmissão de ondas eletromagnéticas e consolidadas pelo rádio e 
pela televisão no século $\mathrm{XX}$ ), passamos a conviver também com novos meios digitais.

Ao longo dos últimos anos, o desenvolvimento das mídias digitais passou por algumas fases distintas. Castells (2003), ao narrar a história da Internet, classificou essas fases em Era Militar (momento em que a Internet nasce como um projeto do Departamento de Defesa dos Estados Unidos, na década de 1960), Era Acadêmica (quando as tecnologias da Internet são de fato desenvolvidas em universidades e centros de pesquisa em tecnologia dos Estados Unidos) e Era Comercial (marcada pelo surgimento da Web, a exploração comercial da sua popularização e a especulação financeira com foco nas empresas do setor ao longo da década de 1990). Posteriormente a essa classificação proposta por Castells (2003), uma outra fase da Internet, mais precisamente da Web, tornou-se evidente.

Após o estouro da bolha financeira causada pela especulação em torno das empresas que atuavam na Web, a Internet perdeu o financiamento de grandes companhias, especialmente ligadas ao setor de telefonia e imprensa, e precisou se reinventar (VIEIRA, 2003). Nesse processo, tornaram-se populares os softwares sociais ou ferramentas capazes de oferecer, ao usuário, mais possibilidades de interação social com seus pares. Essa transformação é chamada de Web Social ou web 2.0 (SPYER, 2007). É nessa fase social que as mídias digitais consolidaram algumas vantagens sobre as chamadas mídias tradicionais (impressas e eletrônicas). Podemos citar como algumas dessas vantagens a interatividade (SANTAELLA, 2004) e a "liberação do polo da emissão" (LEMOS; LEVY, 2010, p. 88), ambas com potencial para gerar no usuário uma postura ativa, conforme será discutido adiante.

A interatividade já era prometida pelo rádio e pela televisão, mas com a Internet avança para níveis mais profundos. Ela é decisiva para a compreensão das mídias digitais, pois se situa na interseção entre as características do próprio meio e o comportamento dos seus usuários. A World Wide Web tem seu princípio de funcionamento baseado no hipertexto, que se caracteriza como um conteúdo descentralizado, composto por diversos blocos de informação interconectados, dispostos em locais e em formatos diferentes e que, por isso, requer a interação (interatividade) do usuário, juntando ou navegando por esses blocos. 
A "liberação do polo da emissão" é descrita como uma profunda mudança nas relações de poder estabelecidas pelos meios de comunicação de massa. Enquanto as mídias impressas e eletrônicas tinham como característica concentrar o poder de voz em um pequeno número de indivíduos ou organizações, as mídias digitais permitem que qualquer pessoa com acesso a rede possa ser um emissor de mensagens para as massas.

Essas duas características das mídias digitais fazem com que elas forcem ao abandono de uma postura passiva, comum quando utilizamos outras mídias, para a adoção de uma postura ativa, seja para consumir conteúdo ou para nos manifestamos por meio da Web. Não esperar passivamente que as informações venham até nós, mas sim buscá-las ativamente no emaranhado de nós e links da World Wide Web e ter a liberdade para, ativamente, buscar a atenção dos demais usuários, produzindo e compartilhando nossos próprios conteúdos são os comportamentos definidores das características do usuário das mídias digitais. Um comportamento que nos coloca em estado de "prontidão sensorial" (SANTAELLA, 2004), que será discutido adiante.

Numa espécie de efeito colateral dessas transformações, no entanto, as redes sociais na Internet também popularizam o recurso das timelines (linhas do tempo) ou news feed, que são ambientes para o consumo de informação dotados de algoritmos que fazem a seleção automática de conteúdos de acordo com o perfil dos usuários, o que nos coloca novamente em uma postura passiva, parecida com aquela que temos ao consumir conteúdo nos meios de comunicação tradicionais. Embora represente uma espécie de retrocesso e diminuição de liberdade, esse tipo de recurso é amplamente aceito pelos usuários, sob a justificativa de que eles permitem maior personalização e comodidade (PARISER, 2012).

Esse artigo tem como objetivo levantar evidências que possam sustentar a afirmação de que a dinâmica dos algoritmos e a arquitetura da informação, tal como são utilizadas nas timelines das redes sociais na Internet, têm o potencial de contribuir para o abandono da postura ativa por parte do usuário da World Wide Web. Para essa finalidade, emprega como metodologia a análise das timelines a partir dos atributos da Encontrabilidade da Informação, conforme propostos por 
Vechiato e Vidotti (2014), que englobam: taxonomias navegacionais; instrumentos de controle terminológico; folksonomias; metadados; mediação dos informáticos; affordances; wayfinding; descoberta de informação; acessibilidade e usabilidade; mediação dos profissionais da informação; mediação dos sujeitos informacionais; intencionalidade e mobilidade; convergência e ubiquidade. O estudo parte do pressuposto de que ambientes informacionais projetados para um usuário ativo precisam de mais recursos para a Encontratiblidade da Informação, ao passo que ambientes projetados para usuários passivos podem prescindir de tais recursos.

Embora seja possível expandir os resultados encontrados para muitas outras plataformas, que possuem timelines com características semelhantes, para essa análise foi selecionada a plataforma de rede social na Internet mais popular no momento, o Facebook (www.facebook.com), que segundo a Statista ([2021]), possuía 2,7 bilhões de usuários ativos em janeiro de 2021. A escolha também se justifica pelo fato de ter sido o Facebook a plataforma precursora na adoção das timelines como principal recurso informacional. A análise busca identificar quais são e como os atributos da Encontrabilidade da Informação são contemplados pela timeline no Facebook.

\section{Prontidão sensorial do leitor imersivo}

Santaella (2004) sustenta que o uso da Internet define um novo estágio na evolução do modo como consumimos conteúdo. Segundo a pesquisadora, começamos a formar nosso comportamento como leitores a partir de meios escritos e impressos, especialmente o livro. Com eles, o homem passou a adotar certos hábitos para a apreensão de novas informações. A leitura do livro é caracterizada pela pausa, ou seja, o indivíduo precisa parar, retirar-se de sua rotina e se concentrar para ler. É uma leitura linear, que precisa obedecer a uma sequência preestabelecida pelas páginas.

Este tipo de leitura nasce da relação íntima entre o leitor e o livro, leitura do manuseio, da intimidade, em retiro voluntário, num espaço retirado e privado, que tem na biblioteca seu lugar de recolhimento, 
pois o espaço de leitura deve ser separado dos lugares de um divertimento mais mundano. (SANTAELLA, 2004, p. 23).

A autora chamou este tipo de comportamento de consumo de informação de "leitor contemplativo" ou "leitor meditativo". "Esse leitor não sofre, não é acossado pelas urgências do tempo. Um leitor que contempla, que medita. Entre os sentidos, a visão reina soberana, complementada pelo sentido interior da imaginação" (SANTAELLA, 2004, p. 24). Mais tarde, com a consolidação do jornal impresso, com a formação das grandes cidades e a migração das populações para os centros urbanos, o comportamento do homem para a apreensão de novas informações mudou. A agitação e o ritmo de vida acelerado das cidades fez nascer o que a autora chama de "leitor movente", que é "[...] o leitor fugaz, novidadeiro, de memória curta, mais ágil. [...] Um leitor de fragmentos, leitor de tiras de jornal e fatias de realidade. (SANTAELLA, 2004, p. 29).

\begin{abstract}
Esbarrando a todo instante em signos, signos que vêm ao seu encontro, fora e dentro de casa, este leitor aprende a transitar entre linguagens, passando dos objetos aos signos, da imagem ao verbo, do som para a imagem com familiaridade imperceptível. Isso se acentua com o advento da televisão: imagens, ruídos, sons, falas, movimentos e ritmos na tela se confundem e se mesclam com situações vividas. (SANTAELLA, 2004, p. 31).
\end{abstract}

Com as mídias digitais, surge um terceiro comportamento de consumo de informações que é chamado por Santaella de "leitor imersivo",

[...] um leitor em estado de prontidão, conectando-se entre nós e nexos, num roteiro multilinear [...] que ele próprio ajudou a construir ao interagir com os nós entre palavras, imagens, documentação, música, vídeo etc. (SANTAELLA, 2004, p. 33).

Daí é possível inferir três fatores característicos do comportamento do usuário das mídias digitais: (1) a prontidão sensorial, (2) a não linearidade da leitura e (3) a interatividade. Essas três características formam a aqui referida postura ativa do usuário. Elas formam o que podemos chamar de linguagem das mídias digitais. Segundo Pereira (2009, p. 641), 
meios (e dos seus espaços), as características materiais do corpo humano, e os usos dos meios (as práticas de comunicação).

A prontidão sensorial caracteriza-se pela não necessidade de pausa ou de "descolamento" do próprio cotidiano para o consumo de informações, descrevendo um envolvimento maior dos sentidos com a experiência midiática. $\mathrm{O}$ apelo aos sentidos também está presente, em alguma medida, nas mídias eletrônicas e urbanas, uma vez que nelas as mensagens estão dispersas no ambiente, oferecendo estímulos que tentam de alguma maneira chamar nossa atenção. A diferença é que nas mídias digitais, o leitor precisa empregar ativamente sua sensorialidade, passando do simples apelo para a imersão do envolvimento, deixando de simplesmente ler e passando a "experimentar" sua relação com a mídia e seu conteúdo (SANTAELLA, 2004).

A não linearidade da leitura nas mídias digitais revela-se como uma forte ruptura em relação ao comportamento comum em outras mídias. No livro, jornal, revistas e até na televisão e no rádio, o receptor espera que as mensagens transcorram diante de si para selecionar aquelas para as quais deve empenhar sua atenção. Ou seja, nas mídias impressas e eletrônicas, as mensagens são lineares, cronológicas e passeiam diante dos sentidos de acordo com uma sequência predeterminada. Nas mídias digitais, no entanto, as mensagens encontram-se fragmentadas, dispersas em diversos locais, em diferentes formatos, e é o leitor quem faz a conexão entre esses fragmentos, no momento em que desejar, na ordem em que desejar. Há aqui, portanto, uma necessidade de ação e de envolvimento mais profundo do leitor com a construção da mensagem, tanto que, tradicionalmente, nestes meios ele é chamado de usuário, ao invés de leitor ou espectador. É essa necessidade de ação que aguça os sentidos e nos coloca em estado de prontidão.

Esse formato de fragmentação da mensagem é o que se designa como hipertexto. "O hipertexto é um documento digital composto por diferentes blocos de informações interconectadas. Essas informações são amarradas por meio de elos associativos, os links" (LEÃO, 1999, p. 15). Além disso, esses fragmentos de mensagem podem ter formatos diferentes, como texto, som, áudio e vídeo, ou mesmo da combinação entre elas. Essa hibridação de linguagens é o que se 
entende como multimídia e o seu entrelaçamento com o hipertexto denomina-se hipermídia. "Hipermídia, por sua vez, é uma tecnologia que engloba recursos do hipertexto e multimídia, permitindo ao usuário a navegação por diversas partes de um aplicativo, na ordem que desejar" (LEÃO, 1999, p. 16).

O receptor de uma hipermídia, ou usuário, como costuma ser chamado, coloca em ação mecanismos, ou melhor, habilidades de leitura muito distintas daquelas que são empregadas pelo leitor de um texto impresso como o livro. Por outro lado, são habilidades também distintas daquelas que são empregadas pelo receptor de imagens ou espectador de cinema, televisão. (SANTAELLA, 2004, p. 11).

A leitura de mensagens em formato hipermidiático transforma o leitor em um agente ativo, chamado de usuário, fazendo com a mensagem somente se concretize quando acessada e combinada com outros fragmentos por ele conhecidos. "O leitor em hipermídia é um leitor ativo, que está a todo momento estabelecendo relações próprias entre diversos caminhos. Como um labirinto a ser visitado, a hipermídia nos promete surpresas, percursos desconhecidos" (LEÃO, 1999, p. 16).

A terceira característica determinante do comportamento do usuário da Internet é a interatividade, que, segundo Santaella (2004, p. 181) é “a grande marca identificatória do leitor imersivo". A interatividade nasce da necessidade de ação por parte do usuário para fazer as conexões entre os blocos do hipertexto (interação com o conteúdo) e se expande para a liberdade de diálogo entre os usuários (interação social). Predispor-se para a interação é uma postura ativa.

Onde se situam as mensagens no ciberespaço? No ponto de emissão ou de recepção? Nem em um, nem em outro, pois elas mais parecem estar no espaço de comutação, que permite conectar o infonauta com seus interlocutores e onde não há lugar para emissores ou receptores definidos, apenas trânsito informacional. (SANTAELLA, 2004, p. 181).

As reflexões acima tornam evidente que o papel que a interatividade, a não linearidade e o envolvimento sensorial do leitor com a mídia são fatores determinantes para a compreensão da linguagem da mídia digital. É a presença desses fatores que colabora para que as mídias surgidas a partir do computador sejam diferentes de outros tipos de mídia já conhecidos. São características que 
empoderam e conferem liberdade ao usuário, no que Lemos e Levy (2010) chamaram de "perspectiva da emancipação" e a consequente "liberação do polo da emissão". Enquanto nas outras mídias o emissor é sempre uma organização empresarial, uma indústria cultural ou alguém com poder suficiente para manipular as massas, na mídia digital todos somos emissores e todos podemos produzir e fazer circular mensagens, sem qualquer controle ou edição.

O potencial de alcance dessa liberação das vozes oprimidas é incalculável. Lévy aponta inclusive no sentido de que impliquem na sobrepujança de regimes totalitários e repressores:

[...] o aperfeiçoamento da inteligência coletiva (que supõe a liberdade) é o produto e o sentido da evolução cultural. É exatamente por essa razão que os regimes de liberdade intelectual e política acabarão por se impor sobre os regimes de ditadura a repressão do pensamento. (LEMOS; LÉVY, 2010, p. 38).

Porém, o que tem se observado mais recentemente é que, embora essa emancipação tenha sido conquistada e permitida pelas mídias digitais ao longo de décadas, como um caminho promissor em direção à liberdade de expressão e informação, atualmente estamos abrindo mão delas, optando por reproduzir, também na Internet, o comportamento passivo que costumamos dedicar aos outros meios. E o que parece estar tolhendo nossa postura ativa é o dos recursos das timelines ou feeds de notícias, adotados maciçamente pelas Redes Sociais na Internet.

\section{A Web Social e as redes sociais na Internet}

É paradoxal que a postura ativa e a liberdade do usuário da Internet começaram a degenerar, exatamente no momento em que a rede ganhava mais liberdade. Entre o final da década de 1990 e começo da década de 2000, a história da rede mundial de computadores foi marcara pelo episódio que ficou conhecido como o estouro da bolha da Internet. Episódio que teve consequências trágicas para empresas e investidores, mas que acabou favorecendo o usuário, colocando-o novamente no papel de protagonista no desenvolvimento da rede. 
A World Wide Web foi criada início dos anos 1990 por Tim Berners-Lee e experimentou uma popularização bastante intensa ao longo de sua primeira década de existência, que foi possível graças a investimentos dos chamados Provedores de Serviço de Internet (PSI).

No início da década de 1990 muitos provedores de serviços de Internet montaram suas próprias redes e estabeleceram suas próprias portas de comunicação em bases comerciais. A partir de então, a Internet cresceu rapidamente [...]. (CASTELLS, 2003, p. 15).

Porém, também durante essa primeira década de existência da Web, a exploração comercial da sua crescente popularidade acabou provocando uma bolha financeira.

O índice Nasdaq saiu de 1500 pontos, em 1998, para uma curva que não iria parar antes dos 5 mil. Ao longo de 1999 ganhou 1876 pontos e $86,59 \%$ de valorização, a maior em seus 28 anos de história (...). Em 14 de abril de 2000, a Nasdaq caiu 355,49 pontos. Entre março e mail de 2000, emagreceu 2,4 trilhões de dólares num tombo espetacular de 37\%. (VIEIRA, 2003, p. 213).

A crise provocada pelo estouro da bolha da Internet afugentou investidores, fechou empresas e fez diminuir os recursos financeiros que sustentavam a expansão da rede. Pelo mesmo motivo, os produtos que eram populares na $W e b$, aos poucos deixaram de existir e foram sendo substituídos por outros, com características diferentes. Na década de 2000, começam a ganhar popularidade na Web os softwares sociais, que oferecem, a seus usuários, recursos para promover a interação social e corroboram sobremaneira a liberação do polo da emissão. "Desde 2002, o termo 'software social' é usado para se referir ao tipo de programa que produz ambientes de socialização pela Internet, ele é o que está por traz da colaboração online" (SPYER, 2007, p. 21). Essa mudança em direção aos softwares sociais ficou conhecida como Web social ou Web 2.0.

Os softwares sociais apresentaram-se inicialmente na forma de chats, comunicadores instantâneos, fóruns, listas de discussão, blogs, fotologs, videologs, wikis e agregadores de conteúdo ${ }^{1}$ com recursos de folksonomia (SPYER, 2007). Evoluíram para o que conhecemos hoje como as redes sociais na Internet. Elas são o tipo software social mais desenvolvido que já tivemos à nossa disposição, pois reúnem características de todos os outros tipos em uma única 
plataforma. É importante ressaltar que redes sociais são um fenômeno que independe de uma plataforma tecnológica. Elas existem e se formam a partir da interação social entre indivíduos, e não de tecnologias. Nesse sentido, o que, no contexto da Web, chamamos de redes sociais são, na verdade, ferramentas tecnológicas que auxiliam e potencializam os indivíduos no gerenciamento de suas próprias redes sociais. Por isso, adotou-se neste trabalho a expressão Redes Sociais na Internet. Essa expressão é utilizada por Recuero (2009) em um estudo sobre esse tema, em que a ela atribui os elementos que compõem uma rede social e discute como eles estão presentes nas ferramentas sociais da Web.

Uma rede social é definida como um conjunto de dois elementos: atores (pessoas, instituições ou grupos; os nós da rede) e suas conexões (interações ou lassos sociais). Uma rede, assim, é uma metáfora para observar os padrões de conexão de um grupo social, a partir das conexões estabelecidas entre os diversos atores. (RECUERO, 2009, p. 24).

O objetivo dos atores ao estabelecer conexões com outros atores e interagir com eles por meio das redes sociais na Internet pode ser entendido como a tentativa de exercer, da melhor maneira possível, sua liberdade como emissor e sua postura ativa como usuário. Segundo Spyer (2007), nas redes sociais, isso é conseguido por meio da cooperação e da colaboração entre os usuários.

A cooperação é, por natureza estática, propicia a discussão a respeito de um problema definido e compartilha as tarefas relacionadas à solução do mesmo. Colaboração é um processo dinâmico cuja meta é chegar a um resultado novo [...] a partir das competências direcionadas dos indivíduos ou grupos envolvidos. (SPYER, 2007, p. 23).

Percebemos com isso que, mesmo nesse momento conhecido como Web social e no uso das ferramentas que conhecemos como redes sociais na Internet, como usuários ainda mantemos uma postura ativa e engajada no consumo e na geração de conteúdos. Porém, como já foi dito, atualmente há um recurso presente nesses nos softwares sociais mais populares que podem silenciosamente nos demover dessa condição, colocando-nos novamente em uma postura passiva. $\mathrm{O}$ que tem provocado isso são as timelines ou feeds de notícias. 


\section{As timelines, seus algoritmos e a passividade dos usuários}

Enquanto num primeiro momento, ainda nos anos iniciais da década de 2000, as plataformas de redes sociais na Internet privilegiavam o perfil do usuário e suas relações sociais (essas eram as informações que apareciam em maior evidência), nos últimos anos, elas adotaram, em massa, o recurso das timeline ou feed de notícias. Com isso, ao acessar esses softwares sociais, os usuários passaram a ver primeiramente esse recurso, e não seu próprio perfil ou suas informações pessoais.

O objetivo das timelines ou feeds de notícias é apresentar, para o usuário, os conteúdos que foram compartilhados recentemente por seus contatos sociais. Porém, dada a grande popularidade desses softwares e o grande volume de conteúdo que é compartilhado o tempo todo, seria inviável que essas páginas apresentassem tudo aquilo que é disponibilizado por nossas redes sociais. "A tarefa de examinar essa torrente cada vez mais ampla em busca dar partes realmente importantes, ou apenas relevantes, já exige dedicação em tempo integral" (PARISER, 2012, p. 16). Para resolver esse problema, aos poucos as principais plataformas de redes sociais na Internet passaram a adotar uma solução no mínimo polêmica: ao invés de exibir todo o conteúdo disponível em ordem cronológica, como era a essência dessas páginas (o próprio nome timeline, ou linha do tempo demonstra isso), foram criados algoritmos que selecionam, filtram e organizam o conteúdo disponível, apresentando-nos apenas aquilo que eles consideram relevantes.

No início, o feed de notícias mostrava quase tudo que nossos amigos faziam no site. No entanto, quando o volume de postagens e amigos aumentou, ler ou gerir o feed tornou-se impossível. Mesmo que tivéssemos apenas cem amigos, era um volume grande demais. (PARISER, 2012, p. 39).

Dessa forma, cada software social estabelece seu próprio critério para definir o que é e o que não é relevante, mas em comum, eles buscam fazer essa seleção com base naquilo que seria do interesse de cada usuário. Quando mais o usuário se interessa por um conteúdo, mais relevante ele é. E, para determinar o que é do interesse do usuário, os algoritmos que fazem essa filtragem de 
conteúdos se apoiam no perfil e nas informações que dispõem sobre os hábitos e costumes sociais de cada usuário.

Assim, quando os filtros personalizados nos oferecem ajuda, temos a tendência de aceitá-la. Em teoria, os filtros podem nos facilitar a encontrar as informações que precisamos conhecer [...], as partes que realmente importam [...]. (PARISER, 2012, p. 16).

A promessa é tentadora, pois com os algoritmos fazendo o trabalho de filtrar e selecionar entre os conteúdos disponíveis aqueles que têm mais chance de ser relevante para cada usuário, "os meios de comunicação serão um reflexo perfeito de nossos interesses e desejos" (PARISER, 2012, p. 17). Mas, olhando pelo ponto de vista da construção da linguagem das mídias digitais conforme discutido aqui, tendo como componente fundamental e distintivo em relação a outras mídias, a postura ativa do usuário, o fenômeno das timelines e dos feeds de notícias controlados por algoritmos que fazem a seleção automática do conteúdo com base nos interesses do usuário, pode ser um retrocesso. Afinal, elas colocam o usuário em uma postura passiva, de simples receptor de informações. Nas plataformas mais populares de redes sociais na Internet, já é comum o comportamento de percorrer ou "rolar" indefinidamente as timelines, sem que se esteja de fato procurando alguma coisa ou prestando atenção em algum conteúdo. Um comportamento que, ao invés de provocar a prontidão sensorial do usuário, causa o entorpecimento dos sentidos em um estado de grande passividade.

Uma preocupação subjacente na construção de ambientes informacionais em que o usuário tem uma postura ativa de busca por conteúdo, como é o caso das mídias digitais, dos softwares sociais e das plataformas de redes sociais na Internet, é a Encontrabilidade da Informação (findability). A seguir, serão apresentados os seus fundamentos e, depois, será discutida sua aplicação nas timelines e nos feeds de notícias.

\section{Encontrabilidade da informação}

Nos ambientes informacionais, a encontrabilidade diz respeito ao grau com que uma determinada informação ou conteúdo é facilmente descoberto ou localizado. Ou seja, um alto grau de encontrabilidade é alcançado pelo ambiente quando ele 
proporciona que o usuário localize os conteúdos que está procurando ativamente ou descubra novos conteúdos, por meio da livre navegação pela totalidade das informações disponíveis (MORVILLE, 2005). Ela depende da convecção entre a intencionalidade do usuário (o que ele procura ativamente) e das funcionalidades oferecidas pelo ambiente informacional para que essa intenção se concretize. "A encontrabilidade da informação sustenta-se fundamentalmente na interseção entre as funcionalidades de um ambiente informacional e as características dos sujeitos informacionais" (VECHIATO; VIDOTTI, 2014).

Embora Morville (2005) tenha apresentado a encontrabilidade em termos do grau com que um conteúdo é facilmente encontrado, sua análise não se realiza necessariamente por meio de uma medição quantitativa. Vechiato e Vidotti (2014) propõem que tal análise se faça por meio do estudo e da avalição qualitativa da presença de certos atributos que compõem a Encontrabilidade da Informação, e como eles são abordados pelo ambiente informacional investigado. De acordo com a proposta dos autores, esses são os atributos da encontrabilidade da informação:

a) Taxonomias navegacionais: organização hierárquica e nomenclatura utilizada no menu de navegação do ambiente informacional;

b) Instrumentos de controle terminológico: uso de vocabulários controlados, glossários ou tesauros;

c) Folksonomias: possibilidade dada aos usuários de criarem mecanismos próprios de classificação, definindo eles mesmos as categorias e a terminologia para a classificação dos conteúdos;

d) Metadados: uso de dados estruturados que descrevem ou representam, de acordo com algum padrão, os objetos informacionais disponíveis no ambiente;

e) Mediação dos informáticos: como o ambiente foi desenvolvido e projetado por seus desenvolvedores para facilitar a apresentação das informações;

f) Affordances: elementos que facilitam o reconhecimento e o entendimento das funcionalidades do ambiente informacional por parte dos usuários; 
g) Wayfinding: uso de metáforas, marcos e indicadores que auxiliam o usuário a se localizar em seu percurso de navegação pelo sistema informacional;

h) Descoberta de informação: capacidade do sistema em oferecer ao usuário a informação que ele está procurando, mas também proporcionar a descoberta acidental de novas informações, selecionadas e ofertadas pelo próprio ambiente;

i) Acessibilidade e usabilidade: acessibilidade refere-se à presença de recursos que permitam o uso do ambiente informacional por pessoas com diferentes condições de acesso à informação. Usabilidade diz respeito ao quanto o sistema é fácil de aprender e fácil de usar sem que ocorram erros ou que, se ocorram, sejam facilmente solucionados;

j) Mediação dos profissionais da informação: atributo mais aplicável a ambientes informacionais analógicos, no qual a presença de um bibliotecário ou arquivista pode facilitar o acesso à informação;

k) Mediação dos sujeitos informacionais: possibilidades ofertadas pelo ambiente para que usuário participe da produção, organização e representação das informações ofertadas pelo ambiente;

1) Intencionalidade: preocupação do ambiente informacional em responder aos comportamentos e às experiências específicas de cada usuário;

m) Mobilidade, convergência e ubiquidade: possibilidade de acesso ao ambiente informacional em qualquer lugar, a qualquer tempo e por diferentes dispositivos.

Considerando-se as timelines e os feeds de notícias como ambientes informacionais, a análise dos atributos da encontrabilidade da informação ajuda a compreender o seu papel e o modo como eles proporcionam a interação dos usuários com os conteúdos. A análise também torna evidente que esses ambientes não são receptivos para uma postura ativa do usuário e privilegiam uma atitude passiva no consumo dos conteúdos. 


\section{Análise dos atributos da encontrabilidade da informação nas timelines}

Essa análise leva em consideração a timeline ou ofeed de notícias especificamente do Facebook. A seguir, são enumeradas algumas características presentes nessa plataforma, mas que também podem ser encontradas em muitas outras similares:

a) Os conteúdos são apresentados sequencialmente na vertical, sendo que o usuário precisa "rolar" a página para baixo para encontrar mais conteúdos;

b) A rolagem da página aparenta ser infinita, de modo que, conforme o usuário chega ao final da página, novos conteúdos são carregados e a rolagem pode continuar indefinidamente;

c) A ordem em que os conteúdos aparecem é decidida arbitrariamente pelo algoritmo do software social a partir de algum critério de relevância, sendo que o usuário tem pouco ou nenhum controle sobre ela;

d) Os usuários podem compartilhar novos conteúdos, que poderão aparecer nas timelines de outros usuários;

e) Os usuários podem indicar seu apreço ou interesse por cada conteúdo da timeline por meio de recursos que marcam os conteúdos que gostou;

f) Os usuários podem interagir com cada conteúdo, acrescentando novas informações por meio de comentários que ficarão visíveis para outros usuários;

g) Tanto nos novos conteúdos como nos comentários os usuários podem classificar os conteúdos por meio de hashtags ${ }^{2}$, que correspondem a um mecanismo de folksonomia;

h) Quanto mais vezes for marcado como gostei e mais comentários receber, mais chance o conteúdo tem de ser selecionado pelo algoritmo para ser exibido para outros usuários.

Com base nessas características, cabe aferir se eles são suficientes ou não para o atendimento dos atributos da Encontrabilidade da Informação e, com essa aferição, buscar compreender o propósito desses ambientes. O Quadro 1 apresenta a análise da relação das timelines e dos feeds de notícias com cada atributo. 
Quadro 1 - Atributos da Encontrabilidade da Informação na Timeline ou no Feed de Notícias do Facebook

\begin{tabular}{|c|c|}
\hline Atributo & Aplicação na timeline ou feed de notícias do Facebook \\
\hline $\begin{array}{l}\text { Taxonomias } \\
\text { navegacionais }\end{array}$ & $\begin{array}{l}\text { Como a timeline é uma página única com rolagem infinita, não há outros } \\
\text { mecanismos de navegação, como menus que requeiram taxonomias } \\
\text { navegacionais. }\end{array}$ \\
\hline $\begin{array}{l}\text { Instrumentos de } \\
\text { controle } \\
\text { terminológico }\end{array}$ & $\begin{array}{l}\text { Não há o uso de qualquer instrumento de controle terminológico ou } \\
\text { vocabulário, de modo que o algoritmo da timeline determina livremente seus } \\
\text { próprios termos. }\end{array}$ \\
\hline Folksonomias & $\begin{array}{l}\text { Esse atributo é alcançado por meio das tags (conhecida como hashtags por } \\
\text { começaram com o caractere \#) que os usuários podem usar tanto nos novos } \\
\text { conteúdos como em comentários. Porém, seu objetivo parece não ser a } \\
\text { classificação em si, mas a alimentação do algoritmo, que pode usar as tags } \\
\text { para recomendar o conteúdo para outros usuários. }\end{array}$ \\
\hline Metadados & $\begin{array}{l}\text { Não existem metadados visíveis, uma vez que não há um índice ou uma } \\
\text { exibição prévia do conteúdo. Cada informação é mostrada diretamente e } \\
\text { integralmente na timeline. }\end{array}$ \\
\hline $\begin{array}{l}\text { Mediação dos } \\
\text { informáticos }\end{array}$ & $\begin{array}{l}\text { A arquitetura da informação da timeline é projetada para ser muito simples, e } \\
\text { não requerer muitas operações do usuário. O modo como os conteúdos são } \\
\text { apresentados também é projetado para que o usuário não precise sair do } \\
\text { ambiente para consumir a informação. Por exemplo: vídeos são assistidos } \\
\text { diretamente na timeline. }\end{array}$ \\
\hline Affordances & $\begin{array}{l}\text { Os indicadores sociais dos conteúdos são mostrados em evidência. O usuário } \\
\text { pode saber quantos outros usuários informaram ter gostado do conteúdo e } \\
\text { quantos comentários ele recebeu. }\end{array}$ \\
\hline Wayfinding & $\begin{array}{l}\text { A navegação é bastante simples, praticamente não há outra ação que o usuário } \\
\text { precise fazer além de rolar a página para baixo para ver mais conteúdos } \\
\text { selecionados pelo algoritmo. Todas as indicações de possiblidades de ação } \\
\text { existentes, como botões para fazer marcações e comentários, dizem respeito a } \\
\text { recursos que podem até serem úteis ao usuário, mas, ao mesmo tempo, servem } \\
\text { como retroalimentação para o algoritmo que poderá usar essas ações para } \\
\text { aperfeiçoar sua seleção. }\end{array}$ \\
\hline $\begin{array}{l}\text { Descoberta de } \\
\text { informação }\end{array}$ & $\begin{array}{l}\text { Como visto, esse atributo tem duas asserções: localização do que o usuário } \\
\text { procura e descoberta de novas informações. A timeline privilegia a descoberta } \\
\text { (passiva) e negligencia a localização (ativa) da informação que o usuário } \\
\text { procura, não oferecendo mecanismos de busca eficientes como forma de } \\
\text { privilegiar as informações mais recentes e relevantes no momento. }\end{array}$ \\
\hline $\begin{array}{l}\text { Acessibilidade e } \\
\text { usabilidade }\end{array}$ & $\begin{array}{l}\text { Parte da atratividade das timelines está em sua simplicidade: basta rolar a } \\
\text { páginas. Essa característica confere boa usabilidade, porém por meio da } \\
\text { simplificação: ao limitar as possibilidades de ação do usuário elas se tornam } \\
\text { fáceis de usar. A timeline do Facebook é precária no que diz respeito à } \\
\text { acessibilidade. Inclusive o uso do mecanismo de rolagem infinita pode ser } \\
\text { desafiador a partir de recursos de acessibilidade, como os leitores de tela. }\end{array}$ \\
\hline $\begin{array}{l}\text { Mediação dos } \\
\text { profissionais da } \\
\text { informação }\end{array}$ & $\begin{array}{l}\text { Esse atributo é mais comum em ambientes informacionais analógicos e não se } \\
\text { aplica às timelines das Redes Sociais na Internet. }\end{array}$ \\
\hline $\begin{array}{l}\text { Mediação dos } \\
\text { sujeitos } \\
\text { informacionais }\end{array}$ & $\begin{array}{l}\text { Os usuários têm liberdade para produzir novos conteúdos ou interferir nos } \\
\text { conteúdos já existentes por meio dos comentários. Porém, como não há um } \\
\text { mecanismo de busca eficiente e os conteúdos mais recentes são privilegiados } \\
\text { em detrimento dos mais antigos, os comentários têm mais impacto na }\end{array}$ \\
\hline
\end{tabular}




\begin{tabular}{|l|l|}
\hline & $\begin{array}{l}\text { retroalimentação do algoritmo e na seleção de conteúdos para outros usuários } \\
\text { do que na construção do conhecimento da comunidade. }\end{array}$ \\
\hline Intencionalidade & $\begin{array}{l}\text { As timelines forçam sua intenção de disseminar os conteúdos mais recentes, e } \\
\text { que foram julgados como mais relevantes pelo algoritmo sobre a intenção dos } \\
\text { usuários. Muitos usuários podem nem perceber que o algoritmo filtra } \\
\text { conteúdos de acordo com seu perfil e suas ações e acabam aceitando } \\
\text { passivamente a seleção feita pelo software. }\end{array}$ \\
\hline $\begin{array}{l}\text { Mobilidade, } \\
\text { convergência e } \\
\text { ubiquidade }\end{array}$ & $\begin{array}{l}\text { As plataformas de redes sociais na Internet costumam atender bem a estes } \\
\text { atributos, uma vez que se esforçam para fazer parte do estilo de vida dos } \\
\text { usuários, de modo que eles possam acessar suas timelines em qualquer lugar } \\
\text { e a qualquer momento por meio uma diversidade de dispositivos. }\end{array}$ \\
\hline
\end{tabular}
Fonte: elaborado pelos autores (2021).

Podemos perceber com essa análise que, no conjunto, as timelines das redes sociais na Internet atendem a poucos atributos da Encontrabilidade da Informação e, quando o fazem, é para promover a passividade diante da seleção de conteúdos feita por seus algoritmos. Esse fato revela que, embora elas façam parte do ambiente mais avançado de interatividade e "liberação do polo da emissão" das mídias digitais, não privilegiam a postura ativa do usuário, pelo contrário, contribuem para a reprodução de uma postura passiva, típica das mídias mais tradicionais.

\section{Considerações finais}

Desde que a $W e b$ surgiu, ela é aclamada por seu potencial de libertação. Por meio dela, as pessoas podem livremente compartilhar informações com muitas outras pessoas, sem a interferência ou anuência de governos ou empresas de mídia. Quando, após o estouro da bolha financeira da Internet, desponta a Web social e seus softwares de gestão de redes sociais, esse potencial libertador parece ganhar impulso, uma vez que confere às pessoas ainda mais possibilidade de interatividade e interação social. Porém, ao que parece, essa perspectiva libertadora tem sido colocada em segundo plano para se privilegiarem outros aspectos, mais ligados à personalização, à comodidade e à simplicidade de uso.

Ao focar sua atenção nesses aspectos, as plataformas de redes sociais na Internet passaram a competir, no sentido de demonstrar qual delas prende a atenção dos usuários por mais tempo, e o caminho para isso tem sido automatizar 
processos, eliminando qualquer necessidade de esforço por parte do usuário. Hoje, é comum passarmos longos períodos simplesmente rolando nossas timelines e nossos feeds de notícias, sem prestar atenção de fato a muita coisa e sem que estejamos necessariamente procurando por algo.

Com isso, estamos abrindo mão de uma postura ativa que sempre caracterizou o usuário das mídias digitais, e voltando a apresentar uma postura passiva, comum nas mídias impressas e eletrônicas. Recebemos uma edição de jornal ou revista impressa e folheamos linearmente página a página, sem poder escolher o conteúdo, que já está todo ali, selecionado por editores e jornalistas. Ligamos a televisão ou o rádio, e já existe um canal sintonizado que começa a despejar informações que não selecionamos, e à qual muitas vezes prestamos pouca atenção. E, agora, acessamos nossas redes sociais na Internet e começamos a rolar nossas timelines, sem escolher ativamente o que vamos ver, esperando sermos surpreendidos por algum conteúdo realmente relevante.

Os atributos da Encontrabilidade da Informação mostraram-se uma eficiente ferramenta para apontar essa mudança de comportamento. Sua análise permite apontar evidências de que as timelines, de fato, foram projetadas para a passividade de um usuário que não procura algo ativamente, mas espera que os conteúdos venham até ele por meio da filtragem e seleção feita automaticamente pelos algoritmos.

\section{Referências}

CASTELLS, Manuel. A galáxia da internet: reflexões sobre a internet, os negócios e a sociedade. Rio de Janeiro: Zahar, 2003.

LEÃO, Lúcia. O labirinto da hipermídia: arquitetura e navegação no ciberespaço. São Paulo: Iluminuras, 1999.

LEMOS, André; LÉVY, Pierre. O futuro da internet: em direção a uma ciberdemocracia planetária. São Paulo: Paulus, 2010.

MORVILLE, Peter. Ambient findability. Sebastopol: O'Reilly Media, 2005.

PARISER, Eli. O filtro invisível: o que a internet está escondendo de você. Rio de Janeiro: Zahar, 2012. 
PEREIRA, Vinícius Andrade. As linguagens publicitárias e os meios digitais. In: CARMELLA, Eliana et al. (org.). Mídias: multiplicação e convergências. São Paulo: Editora SENAC, 2009. p. 637-650.

RECUERO, Raquel. Redes sociais na internet. Porto Alegre: Sulina, 2009.

SANTAELLA, Lucia. Navegar no ciberespaço: o perfil cognitivo do leitor imersivo. São Paulo: Paulus, 2004.

SPYER, Juliano. Conectado: o que a internet fez com você e o que você pode fazer com ela. Rio de Janeiro: Zahar, 2007.

STATISTA. Most popular social networks worldwide as of January 2021, ranked by number of active users (in millions). [S. l.]: Statista, [2021]. Disponível em: https://www.statista.com/statistics/272014/global-socialnetworks-ranked-by-number-of-users/. Acesso em: 18 fev. 2021.

VECHIATO, Fernando Luiz; VIDOTTI, Silvana Aparecida Borsetti Gregorio. Encontrabilidade da informação. São Paulo: Cultura Acadêmica, 2014.

VIEIRA, Eduardo. Os bastidores da internet no Brasil: as histórias de sucesso e fracasso que marcaram a Web brasileira. Barueri: Manole, 2003.

\title{
Information Findability Attributes and Demobilization of the Web User's Active Attitude
}

\begin{abstract}
The World Wide Web revolutionized the way we consume information, demanding from its users an active posture in the search for content. More recently, Social Networks on the Internet offered even more freedoms and possibilities for action to users, but they were also responsible for popularizing the information environments known as timelines. In these environments, the content presented to users is automatically selected by algorithms. This article shares a study that aims to show that the algorithms dynamics and information architecture used in timelines contribute to the return the users to a passive posture. For this purpose, it uses as methodology the analysis of the attributes of Information Findability, verifying how they are applied in timelines. With this analysis, evidence was found that such environments meet a few attributes of Information Findability, allowing to conclude that they were designed for an uninterested user, who does not actively search for information.
\end{abstract}

Keywords: Information findability. Social networks on the internet. Social web. Timelines. 
Recebido: 03/06/2020

Aceito: 04/11/2020

\section{Declaração de autoria}

Concepção e elaboração do estudo: Sergio Mari Junior, Miguel Luiz Contani

Coleta de dados: Sergio Mari Junior

Análise e discussão de dados: Sergio Mari Junior, Miguel Luiz Contani

Redação e revisão do manuscrito: Sergio Mari Junior, Miguel Luiz Contani

\section{Como citar}

MARI JUNIOR, Sergio; CONTANI, Miguel Luiz. Atributos da encontrabilidade da informação e a desmobilização da postura ativa do usuário da Web. Em Questão, Porto Alegre, v. 27, n. 2, p. 193-212, abr./jun. 2021.

doi: http://dx.doi.org/10.19132/1808-5245272.193-212

${ }^{1}$ Fotologs e videologs são páginas de Internet que privilegiam os formatos de foto e vídeo respectivamente e, assim como os blogs, são diários digitais, que apresentam os conteúdos em ordem cronológica inversa (do mais recente para o mais antigo). Wikis são plataformas para a criação colaborativa de conteúdo, sendo a enciclopédia online Wikipedia o exemplo mais conhecido. Agregadores são plataformas utilizadas para a curadoria de conteúdo digital, em que conteúdos sobre um mesmo tema, mas de diversas fontes, são reunidos em um único lugar.

2 Hashtags são etiquetas textuais criadas pelos próprios usuários para indexar conteúdos relacionados. São formadas por uma expressão qualquer precedida pelo caractere \#. 